\title{
Reproductive Hormones Modify Reception of Species-Typical Communication Signals in a Female Anuran
}

\author{
Kathleen S. Lynch ${ }^{a}$ Walter Wilczynskia, b

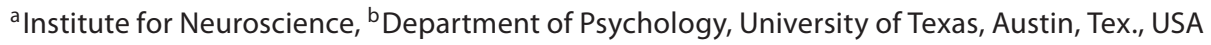

\section{Key Words}

Amphibian · Acoustic communication • Midbrain •

Gonadotropin $\cdot$ Immediate early genes

\section{Abstract}

In many vertebrates, the production and reception of species-typical courtship signals occurs when gonadotropin and gonadal hormone levels are elevated. These hormones may modify sensory processing in the signal receiver in a way that enhances behavioral responses to the signal. We examined this possibility in female túngara frogs (Physalaemus pustulosus) by treating them with either gonadotropin (which elevated estradiol) or saline and exposing them to either mate choruses or silence. Expression of an activity-dependent gene, egr-1, was quantified within two sub-nuclei of the auditory midbrain to investigate whether gonadotropin plus chorus exposure induced greater egr-1 induction than either of these stimuli alone. The laminar nucleus (LN), a sub-nucleus of the torus semicircularis that contains steroid receptors, exhibited elevated egr-1 induction in response to chorus exposure and gonadotropin treatment. Further analysis revealed that neither chorus exposure nor gonadotropin treatment alone elevated egr-1 expression in comparison to baseline levels whereas gonadotropin + chorus exposure did. This suggests that mate signals and hormones together produce an additive effect so that together they induce more egr-1 expression than either alone. Our previously published studies of female túngara frogs reveal that (1) gonadotropin-induced estradiol elevations also in-
\end{abstract}

\begin{tabular}{ll}
\hline KARGER & $\oplus$ 2007 S. Karger AG, Basel \\
Fax +41613061234 & \\
$\begin{array}{l}\text { E-Mail karger@karger.ch } \\
\text { www.karger.com }\end{array}$ & $\begin{array}{l}\text { Accessible online at: } \\
\text { www.karger.com/bbe }\end{array}$
\end{tabular}

crease behavioral responses to male signals, and (2) reception of male signals elevates estradiol levels in the female. Here, we report data that reveal a novel mechanism by which males exploit female sensory processing to increase behavioral responses to their courtship signals.

Copyright $\odot 2007$ S. Karger AG, Basel

\section{Introduction}

Animal communication involves the production of species-typical signals that generally evoke a response in the receiver [Ryan, 1980; Searcy, 1992]. In many vertebrates, the production and reception of species-typical courtship signals occurs during the breeding season, when gonadotropin and gonadal hormone levels are elevated. Elevated gonadotropin and gonadal hormone levels are associated with increased signal production in a wide range of vertebrates and with an increase in the likelihood of evoking a behavioral response in signal receivers [Marler and Ryan, 1996; Thompson and Moore, 2003; for reviews see Ball et al., 2003; Bass and Zakon, 2005; Wilczynski et al., 2005]. One possible means by which these hormones might enhance behavioral responses in the signal receiver is by modifying the way in which the receiver processes the signal. Such hormone-dependent modification of signal processing occurs in several vertebrates, including humans [Hinde and Steele, 1964; Komisaruk et al., 1972; Wright and Crow, 1973; Elkind-Hirsch et al. 1992; Penna et al., 1992; Sisneros et al., 2004; Wal-

Kathleen S. Lynch

Psychological and Brain Science

Johns Hopkins University, Ames Hall 3400 North Charles Street

Baltimore, MD 21218-2686 (USA)

Tel. +1 410516 5148, Fax +1 410516 4478, E-Mail lynchks@jhu.edu 


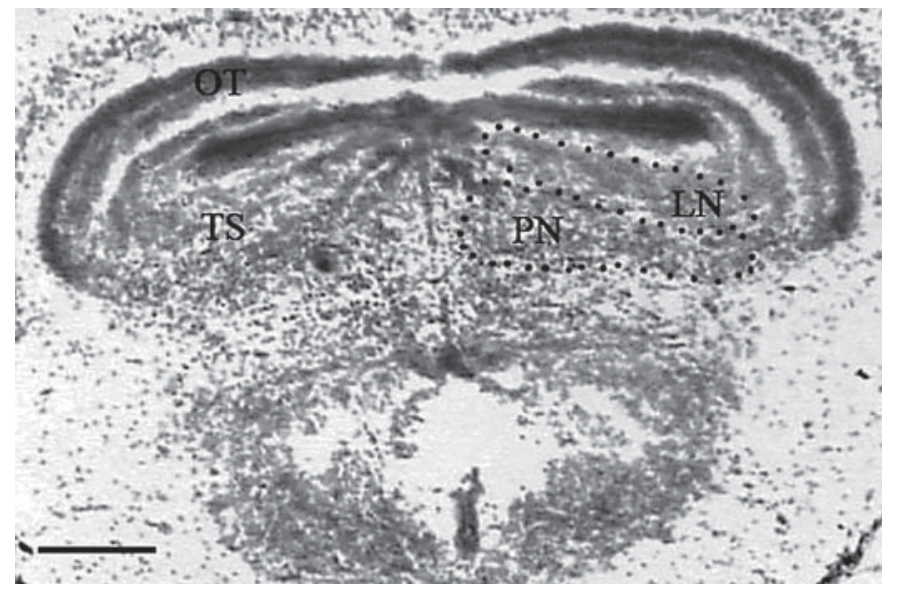

Fig. 1. A section stained with cresyl violet showing the sub-nuclei in the torus semicircularis (TS) within the auditory midbrain of a female túngara frog. The TS is comprised of sub-nuclei, two of which are delineated. The division of these sub-nuclei can be distinguished by connections, cytoarchitecture, and chemoarchitecture. The laminar nucleus (LN) contains cell layers extending from the edge of the optic tectum (OT). The principal nucleus (PN) contains densely packed cells below the LN.

purger et al., 2004; Maney et al., 2006; see Zakon and Smith, 2002, for review], and such plasticity might even serve as an adaptable mechanism by which communication between sender and receiver is improved during the breeding season [Sisneros et al., 2004].

The production and reception of species-typical vocal signals is essential for male and female anurans to coordinate breeding behaviors [Wells, 1977]. Female anurans depend on the male's vocalizations to guide them toward him, a behavior referred to as phonotaxis. Phonotaxis behaviors are most robust when gonadal hormones are naturally elevated [Lynch and Wilczynski, 2005], and can be induced via peptide and gonadal hormone manipulation [Schmidt, 1984, 1985; Lynch et al., 2006]. Although it is not clear exactly which hormone or suite of hormones regulate phonotaxis behavior, we have previously reported that phonotaxis can be evoked using a gonadotropin hormone that in turn elevates gonadal steroid hormones, specifically estradiol, thus indicating that gonadotropin and gonadal hormones are involved in regulating phonotaxis. Here, we investigate whether the same gonadotropin modifies auditory processing of species-typical vocal signals in female túngara frogs (Physalaemus pustulosus).

Gonadotropin-induced modification of auditory processing is possible within the anuran auditory midbrain because one nucleus within this region contains steroid receptors [Kelley et al., 1975, 1978; Morrell et al., 1975; Kelley, 1980; di Meglio et al., 1987]. This nucleus is referred to as the torus semicircularis (TS) [Endepols et al., 2003] and is considered to be the homolog of the mammalian inferior colliculus [Wilczynski and Endepols, 2007]. It serves as a convergence point for parallel ascending auditory pathways, receives ascending and descending auditory inputs, and acts as a sensorimotor integrator [Wilczynski, 1988; Wilczynski and Endepols, 2007]. It is comprised of several sub-nuclei, of two of which the function is well understood. These sub-nuclei are the principal nucleus (PN) and the laminar nucleus (LN; fig. 1). The distinction between these sub-nuclei can be made on the basis of connections, cytoarchitecture, and chemoarchitecture [Potter, 1965; Endepols and Walkowiak, 2001; Wilczynski and Endepols, 2007]. The LN is the major output nucleus of the TS and has extensive connections to premotor and motor areas. Therefore, the LN acts as the audiomotor integrator [Endepols and Walkowiak, 2001]. The PN receives the majority of ascending auditory inputs and sends efferent connections to the thalamus, which in turn projects to the preoptic area, ventral hypothalamus and striatum [Wilczynski et al., 1993; Wilczynski and Endepols, 2007]. Because the hypothalamus receives auditory information via the thalamus, hypothalamic neurons respond to acoustic stimulation in male [Wilczynski and Allison, 1989; Allison, 1992] and female anurans [Hoke et al., 2005]. Consequently, the reception of communication signals induces hormone production in male [Burmeister and Wilczynski, 2000, 2001; Chu and Wilczynski, 2001] and female anurans [Lynch and Wilczynski, 2006].

Here, we investigate whether gonadotropin elevates activity-dependent gene expression in the auditory midbrain during the reception of species-typical signals. To assess this, we measured the induction of one activitydependent immediate early gene (IEG), referred to as egr-1 (early growth response 1). Activity-dependent immediate early genes, such as egr-1, are thought to be involved in a cascade that couples neuronal activation to long-term cellular changes [Clayton, 2000] and, therefore, these genes are frequently used in communication studies as a measure of neural activation [Mello et al., 2004; Hoke et al., 2004, 2005]. We address a question central to understanding how gonadotropic and gonadal steroid hormones act to coordinate breeding attempts between males and female anurans. We ask whether these hormones, which facilitate the production of species-typical vocal signals, also modify the processing of those signals in the receiver. 


\section{Materials and Methods}

\section{Experimental Design}

Female frogs were collected in Gamboa, Panama, in July, 2004. All females in this study released their eggs and were then kept in acoustic isolation at the Smithsonian Tropical Research Institute for 15 days while reproductive hormones dissipated [Lynch and Wilczynski, 2005]. Females were housed in 10 gallon aquaria with five frogs per aquarium. Each aquarium contained water and a deep layer of leaf litter. A single toe clip distinguished the frogs from one another. Frogs were fed termites every other day. At 15 days post egg-laying, females were subcutaneously injected with either saline $(\mathrm{n}=14)$ or 500 IU human chorionic gonadotropin (HCG; $\mathrm{n}=14$ ) in a $50 \mu \mathrm{l}$ volume. HCG administration followed the same procedures as in Lynch et al. [2006] in which we report the minimum HCG dose that elicits behavioral responses and the time required for this to occur. HCG is a ligand for luteinizing hormone receptors and to a lesser extent, follicle stimulate hormone receptors [Costagliola et al., 2005]. Therefore, HCG induces the production of gonadal steroids. After injection, females were placed in plastic bags with water and housed in sound attenuation boxes overnight. The plastic bags are acoustically transparent [Ryan and Rand, 1998]. Approximately 24 hours later, half of the females in the saline and HCG groups were exposed to natural mate choruses and the other half received no acoustic stimulation. The groups are as follows: saline + silence $(n=7)$; saline + chorus $(\mathrm{n}=7) ;$ HCG + silence $(\mathrm{n}=7) ;$ HCG + chorus $(\mathrm{n}=7)$. The mate choruses were broadcast with the peak amplitude at $88 \mathrm{~dB}(20 \mu \mathrm{Pa}$, respectively) for $30 \mathrm{~min}$. Females were rapidly sacrificed via decapitation immediately after acoustic exposure (or exposure to silence). In order to capture mRNA that is expressed in response to only the acoustic stimulus, we needed to have the brain frozen almost immediately after the chorus exposure ended. Therefore, after rapid decapitation, the whole skull was placed in Optimal Cutting Temperature (OCT) embedding medium and flash frozen in liquid nitrogen, thereby eliminating the time required to remove the brain tissue from the skull, which ensured that the brain tissue would be frozen instantly after decapitation. The tissue was then shipped to University of Texas at Austin on dry ice, and stored at $-80^{\circ} \mathrm{C}$. The entire skull including the brain tissue was sectioned on a cryostat at $16 \mu \mathrm{m}$ thickness onto Superfrost Plus slides (Fisher Scientific, Santa Clara, Calif., USA) and stored at $-80^{\circ} \mathrm{C}$ until processed for in situ hybridization.

\section{Hormone Assays}

We did not collect blood via the orbital sinus in the experimental animals because the puncture would significantly stress the animals, which might have impacted IEG expression. Therefore, the efficacy of HCG treatment was assessed in a separate group of females treated with HCG or saline. Blood was collected from these females approximately $24 \mathrm{~h}$ following treatment via orbital sinus puncture. These females were not sacrificed. Blood was centrifuged immediately and the plasma layer removed and placed in liquid nitrogen. The plasma was shipped to University of Texas on dry ice and stored at $-20^{\circ} \mathrm{C}$ until assayed. Plasma volumes ranged from 5-20 $\mu \mathrm{l}$. We used the plasma to first assay progesterone concentrations ( $\mathrm{n}=14 \mathrm{HCG} ; \mathrm{n}=10$ saline) and the remaining plasma was used to assay estradiol concentrations ( $\mathrm{n}=11 \mathrm{HCG} ; \mathrm{n}=8 \mathrm{sa}$ line). $20 \mu \mathrm{l}$ of tritiated hormone (approximately $1,000 \mathrm{cpm}$ ) was added to each plasma sample. Hormones were extracted from the plasma using $3 \mathrm{ml}$ of diethyl ether. Estradiol and progesterone concentrations were assayed using enzyme-linked immunosorbent (EIA) kits (Caymen Chemical; Ann Arbor, Mich., USA). The intra-assay variation was 14.2 and $8.5 \%$ for progesterone and estradiol, respectively. Each hormone was measured on a single plate. The progesterone EIA kits have $61 \%$ cross reactivity with pregnenolone, $7.2 \%$ for $17 \beta$-estradiol, and $6.7 \%$ with $5 \beta$-pregnan$3 \alpha$-ol-20-one. The detection limit of the progesterone kit is 10 $\mathrm{pg} / \mathrm{ml}$. The estrogen EIA kits have a $0.1 \%$ cross reactivity with testosterone and $5 \alpha$-DHT, $0.07 \%$ for $17 \alpha$-estradiol, and $0.03 \%$ for progesterone and the detection limit is $8 \mathrm{pg} / \mathrm{ml}$.

A Kolmogorov-Smirnov test revealed that the hormone concentration data were normally distributed. Comparison of progesterone and estrogen concentrations was done using independent samples $t$ test. All reported values are mean \pm SE.

\section{egr-1 mRNA in situ Hybridization}

Plasmids containing egr-1 DNA were obtained from K. Hoke and S. Burmeister. The plasmids were linearized by digestion with EcoRV and BamHI enzymes (InVitrogen; Carlsbad, Calif., USA). Linearized DNA was then purified using Qia quick Gel Extraction Kit (Qiagen; Valencia, Calif., USA) and the concentration of linear DNA was measured using mass spectrophotometry. Linear strands were used as a template to assemble a complimentary radiolabeled RNA probe (S35, Amersham; Piscataway, N.J., USA) using T7 (sense) and SP6 (antisense) polymerase enzymes (Maxiscript kit, Ambion; Austin, Tex., USA). Radiolabeled probes were purified using NucAway spin columns (Ambion). The quality of the probe was assessed using gel electrophoresis and the quantity was measured in a scintillation counter.

All tissue samples were simultaneously processed for egr-1 in situ hybridization following procedures in Hoke et al. [2004, 2005, 2007]. After hybridization, the slides were dipped in $37^{\circ} \mathrm{C}$ Kodak NTB2 emulsion (VWR Scientific, Brisbane, Calif., USA), wrapped in light proof boxes and exposed in $4^{\circ} \mathrm{C}$ for 35 days. Tissue was developed with D19 developer (VWR) and Kodak fixer (VWR) then counterstained with cresyl violet and coverslipped with Permount (Fisher Scientific).

\section{egr-1 Quantification and Analysis}

A negligible amount of silver grains was found on tissue hybridized with sense probe and on background regions of the slide (i.e., areas with no tissue). The density of silver grains on the tissue hybridized with antisense probe was measured in two subnuclei of the TS, the PN and the LN (see fig. 1). Sections that were torn, folded or badly angled were excluded from the quantification. This reduced the overall sample size (see fig. $2 a$, b for sample sizes). Four tissue sections representing the caudal TS were chosen for each subject and were separate from each other by at least $32 \mu \mathrm{m}$. Five photomicrographs were taken using a $100 \times$ objective (Olympus B $\times 60$ microscope; Optronics camera) using systematic random sampling. We started sampling at the lateral most point of each nucleus and moved toward the midline in $150 \mu \mathrm{m}$ increments. Adobe Photoshop 7 was used to create digital grayscale versions of the photomicrographs, which were used to estimate the density of silver grains on top of cells (fig. 3). NIH Image J software was used to calculate the area of each digital photograph covered by cells and the area covered by silver grains. The mean cell area covered by silver grain pixels was calculated for each subject. 

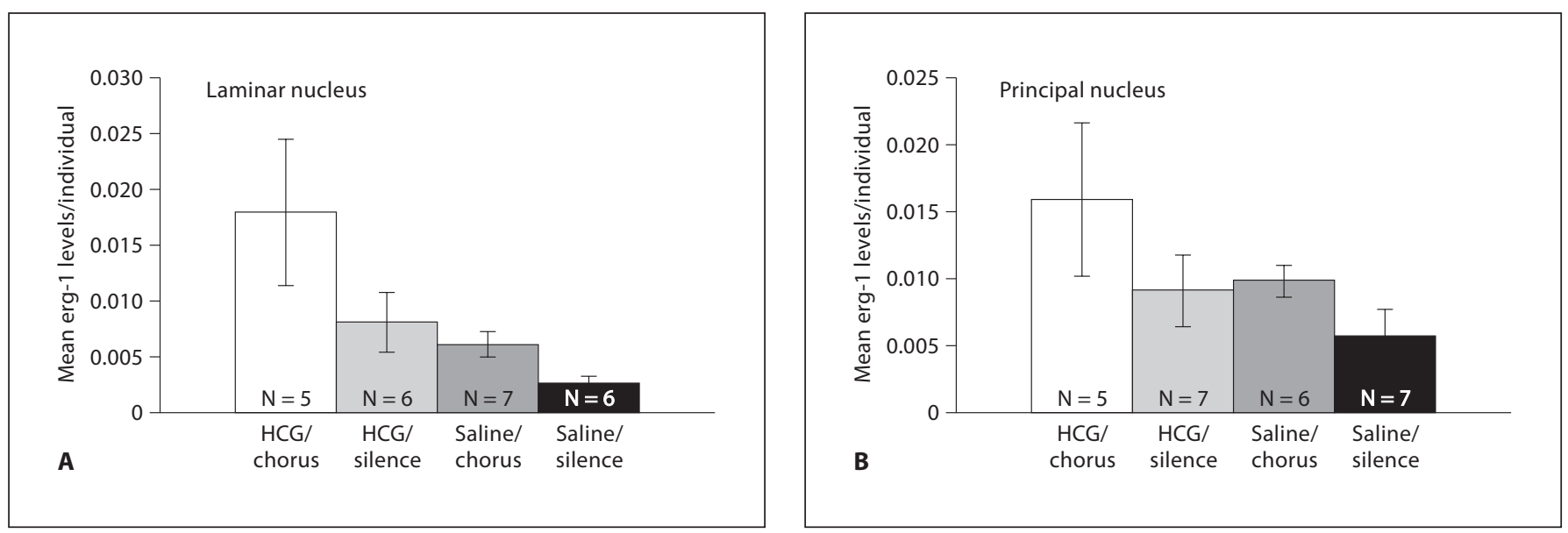

Fig. 2. A Mean egr-1 mRNA levels in the laminar nucleus (LN) of females treated with human chorionic gonadotropin (HCG) or saline then exposed to natural mate choruses or silence. B Mean egr-1 mRNA levels in the principal nucleus (PN) of females treated with human chorionic gonadotropin (HCG) or saline then exposed to natural mate choruses or silence.

Fig. 3. Four photomicrographs representing the quantitative difference in egr-1 mRNA expression in the laminar nucleus. A $E g r-1$ mRNA in saline/silence condition B Egr-1 expression in the saline/chorus condition. C Egr-1 expression in the HCG/ silence condition. D Egr-1 expression in the HCG/chorus condition. These photographs are four of those used for quantitative analysis. The area within the field of view covered by black spots (silver grains) was counted to determine the amount of egr-1 expression. Cell bodies were stained with cresyl violet and the area was calculated to determine the area of the frame covered by cells. Scale bar $=1 \mu \mathrm{m}$.
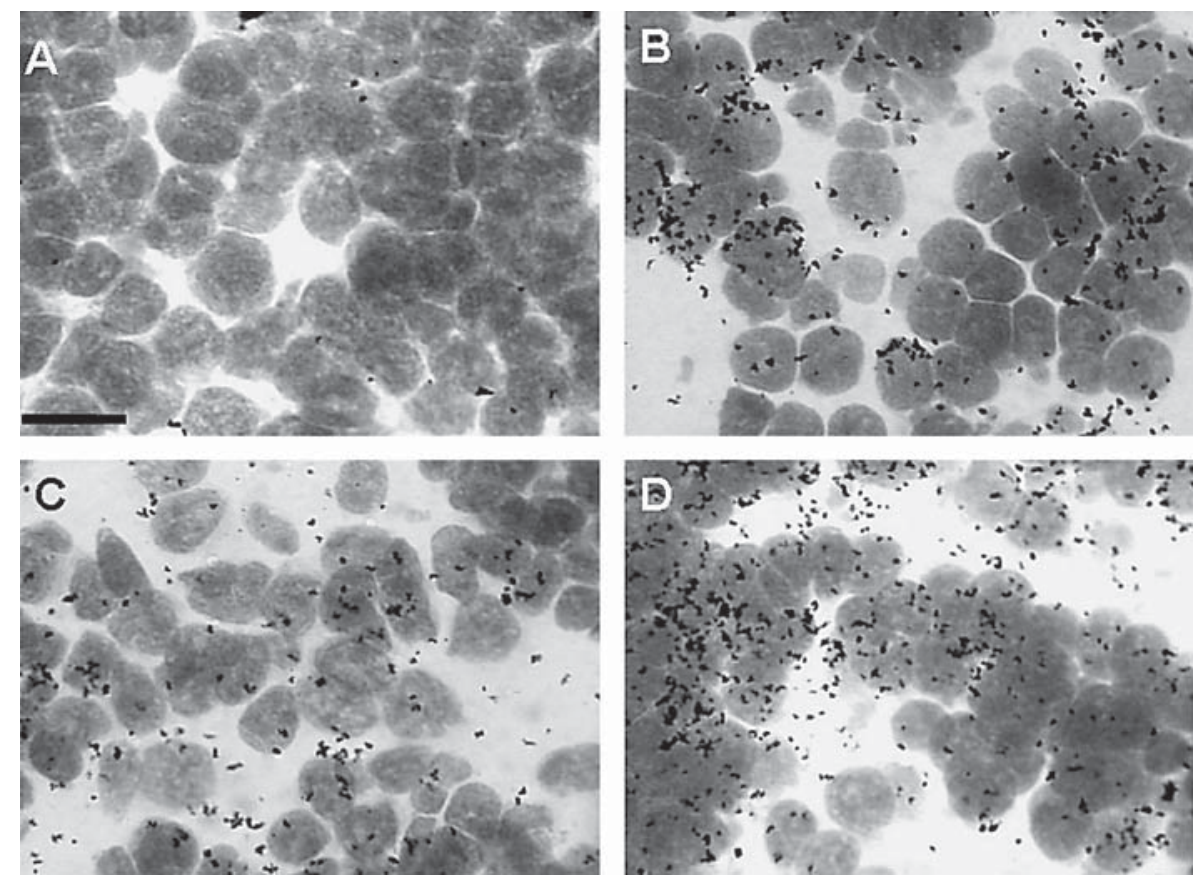

\section{Statistical Analysis}

A Kolmogorov-Smirnov test revealed that these data were normally distributed but the variances were not homogeneous. Log transformation of the data caused the variances to be almost homogenous and parametric statistics are robust to small violations in this assumption [Zar, 1996]. However, the conclusions re- mained unchanged whether we used logarithmically transformed data or our original data in a two-way ANOVA. The two-way ANOVA analyzed the main effect of gonadotropin and/or chorus exposure on egr-1 induction. We also examined whether gonadotropin induced greater egr-1 induction than the other treatments. Therefore, we also examine the effect of gonadotropin on egr-1 
induction using a one-way ANOVA with Tukey's post-hoc tests to determine which groups expressed significantly different egr-1 levels. All reported values are mean \pm SE. Alpha values were set at 0.05 .

\section{Results}

\section{Hormone Assays}

Estradiol concentrations were significantly elevated in females receiving $500 \mathrm{IU}$ of HCG in comparison to females injected with saline $(\mathrm{t}=-3.7 ; \mathrm{p}=0.006)$, indicating that HCG is effective at elevating estradiol levels. The mean concentration of estradiol in saline injected females was $0.44 \pm 0.31 \mathrm{ng} / \mathrm{ml}$, whereas the mean concentration of estradiol in HCG injected females was $10 \pm 2.58 \mathrm{ng} /$ $\mathrm{ml}$. Estradiol concentrations were within physiological range [Lynch and Wilczynski, 2005]. The mean concentration of progesterone in saline and HCG injected females was $3.53 \pm 0.44 \mathrm{ng} / \mathrm{ml}$ and $3.91 \pm 0.54 \mathrm{ng} / \mathrm{ml}$, respectively. There was no significant difference in progesterone concentration between HCG and saline groups $(\mathrm{t}=-0.51 ; \mathrm{p}=0.62)$.

\section{Expression of egr-1 in the $L N$}

The results of the two-way ANOVA revealed that in the laminar nucleus there was a significant elevation in egr-1 expression in females exposed to mate choruses as compared to the females exposed to silence (fig. $2 \mathrm{a} ; \mathrm{n}=$ $24 ; \mathrm{DF}=1,20 ; \mathrm{F}=4.61 ; \mathrm{p}=0.04)$. There was also a significantly higher expression of egr-1 in females treated with HCG as compared to females treated with saline (fig. $2 \mathrm{a} ; \mathrm{DF}=1,20 ; \mathrm{F}=7.83 ; \mathrm{p}=0.011$ ). There was no significant interaction between hormone and acoustic treatment in the $\mathrm{LN}(\mathrm{DF}=1,20 ; \mathrm{F}=1.04 ; \mathrm{p}=0.319)$. The oneway ANOVA revealed that the egr-1 levels were significantly different among the different treatment groups $(\mathrm{F}=4.06 ; \mathrm{DF}=3 ; \mathrm{p}=0.02)$. Tukey's post-hoc comparisons revealed which groups were significantly different from each other. There was an almost significant elevation in egr-1 levels between the chorus-exposed groups if HCG was administered $(\mathrm{p}=0.06)$. In addition, when HCG + chorus exposure are presented together, egr-1 levels are significantly different from baseline (HCG/chorus vs. saline/silence; $\mathrm{p}=0.015)$. No other pairwise comparisons revealed a significant difference between groups.

\section{Expression of egr-1 in the $P N$}

In the principal nucleus, there was no significant elevation in egr-1 expression in females exposed to mate choruses as compared to the females exposed to silence $(\mathrm{n}=25 ; \mathrm{DF}=1,21 ; \mathrm{F}=2.2 ; \mathrm{p}=0.15)$. There was also no significant elevation in egr-1 expression in females treated with HCG when compared to females treated with saline $(\mathrm{DF}=1,21 ; \mathrm{F}=1.64 ; \mathrm{p}=0.21)$ and no significant interaction between these two factors $(\mathrm{DF}=1,21 ; \mathrm{F}=0.15$; $\mathrm{p}=0.70$; fig. 2b).

\section{Discussion}

Egr-1 levels are significantly elevated within the auditory midbrain of the female túngara frog when they are exposed to natural mate choruses or when they are treated with a gonadotropin. This effect occurs specifically in the laminar nucleus within the auditory midbrain. The LN projects to and receives input from motor control regions. Elevated motor-driven egr-1 induction does not occur within the LN [Hoke et al., 2007], however, the LN clearly relays auditory information to forebrain motor areas, indicating that in one sense it does indeed function as a sensorimotor integrator [Wilczynski and Endepols, 2007]. Therefore, it is unclear whether hormonal modification of neural responses within the LN alters sensory processing or whether it alters the integration of sensorymotor information or both. Nonetheless, alteration of either of these processes could ultimately alter behavioral responses [Thompson and Moore, 2000; Rose and Moore, 2002]. Although a similar pattern of egr-1 expression occurs within the principal nucleus within the auditory midbrain, egr-1 levels are not significantly elevated in response to natural mate choruses or gonadotropin treatment. This result might be due to the increased variability of egr-1 expression within the PN. Such variability requires a larger sample size to detect the effects of chorus exposure and gonadotropin treatment on egr-1 expression in the PN.

Significantly elevated chorus-induced egr-1 induction occurs within the LN in male [Hoke et al., 2004] and female túngara frogs [this study]. However, our present data reveals that in female túngara frogs chorus-induced egr-1 expression in the LN is enhanced after gonadotropin treatment. Pair-wise comparisons among experimental groups indicate that neither gonadotropins nor chorus exposure presented on their own induced a significant increase in egr-1 levels as compared to baseline levels. Furthermore, the level of egr-1 induction after hormone administration is roughly equivalent to the level of induction that occurs when mate signals are presented alone. However, presenting these two stimuli together 


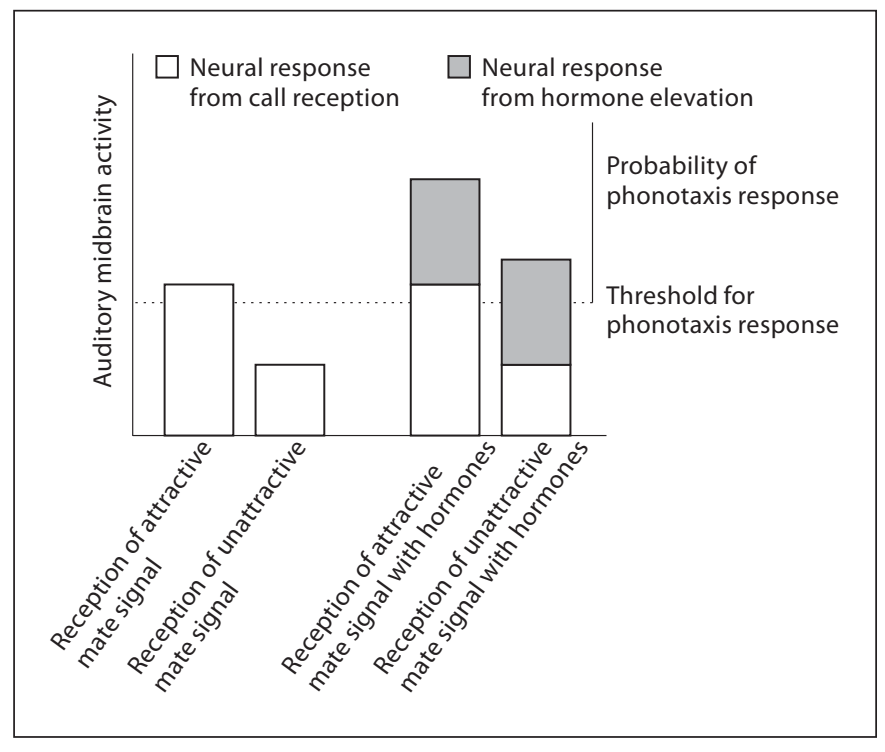

Fig. 4. Simple model illustrating how gonadotropin-induced modification of neural responses in the auditory midbrain might evoke behavioral responses. Auditory midbrain responses to species-typical signals are increased in the presence of gonadotropin and gonadal hormones. Behavioral responses to species-typical courtship signals also increase in the presence of these hormones. Gonadotropin-induced modification of neural responses in the auditory midbrain may also evoke behavioral responses to less attractive species-typical signals.

produces an additive effect so that the two together induce more egr-1 expression than either alone. In essence, the hormone elevation makes the calls twice as stimulating to the auditory system than they would be otherwise.

In birds and anurans, the amount of activity-dependent gene expression that a signal induces within the auditory system often reflects the behavioral relevance of that signal [Mello et al., 2004]. For instance, greater activity-dependent gene induction occurs in auditory processing nuclei in response to species-typical signals as compared to non-typical signals [Hoke et al., 2004; Mello et al., 2004] and in response to attractive species-typical signals as compared to less attractive signals [Gentner et al., 2000; Sockman et al., 2002; Leitner et al., 2005]. These genomic auditory responses mirror behavioral responses in that attractive, species-typical signals are also more likely to evoke behavioral responses. In fact, Maney et al. [2003] reported that elevated activity-dependent gene expression within the female songbird's auditory forebrain occurs in response to songs that also elicit a copulation solicitation display. In male túngara frogs, a greater ge- nomic response is elicited in the LN when males are exposed to species-typical signals as opposed to non-typical signals [Hoke et al., 2004]. Because we did not present females with sounds other than mate chorus, our data do not reveal whether this effect also occurs in female túngara frogs. However, we do know that gonadotropin and gonadal hormones alter the likelihood of a behavioral response to male mate signals and this behavioral change is reflected in the gonadotropin-induced alteration of egr-1 within the auditory midbrain. As gonadotropin [Lynch et al., 2006] and gonadal steroid hormones elevate, there is a concurrent increase in the female's responses to conspecific signals as well as the range of signals the female will accept [Lynch and Wilczysnki, 2005; Lynch et al., 2006]. Thus, as gonadotropin and/or gonadal steroid concentrations rise, females become much more likely to respond to species-typical signals but also become less selective about the signals they will accept. Therefore, even though our data cannot reveal whether egr-1 induction is elevated in response to species-typical signals as opposed to heterospecific signals or sound in general, as is the case in birds, we show that egr-1 expression induced by species-typical signals is elevated even further by gonadotropin injections. So, even if gonadotropin were to enhance neural responses to non-typical signals as well, this would likely still result in an increase in behavioral response to species-typical signals, albeit with a concurrent increase in 'errors' or 'mistakes' in the behavioral response (i.e., responses to unattractive or even heterospecific signals; presented as a simple model in fig. 4). This is, in fact, the pattern of behavioral responses that we have previously reported [Lynch et al., 2006]. Future studies will reveal whether gonadotropin also alters egr-1 levels in response to less attractive species-typical signals that are known to elicit a behavioral response when gonadotropin and gonadal hormones are elevated.

The current study, in combination with our previous studies, presents an intriguing mechanism by which male túngara frogs might exploit the female's auditory system in such a way that increases responses to their calls. That is because when a female is exposed to calling males for a number of days, her estradiol levels will significantly increase [Lynch and Wilczynski, 2006]. This increase in estradiol will, in turn, play a role in increasing the stimulatory effect that the male's call has on the female's auditory system [present data] and in turn, this might enhance the probability that the female will respond to the calling male [Lynch et al., 2005, 2006]. This presents an unusual mechanism by which males may exploit the fe- 
male's auditory system in such a way that will enhance the probability of a response to their own calls.

Gonadotropin-induced modification of behavioral responses and possibly egr-1 responses in the auditory midbrain might occur due to gonadotropin-induced alterations in a suite of other hormones. For instance, in female Xenopus laevis, receptivity to male signals increased with estrogen and progesterone administration; however, the greatest display of receptivity occurred when these gonadal hormones were paired with HCG injections [Kelley, 1982]. In female túngara frogs, the gonadotropin elevates estradiol levels, which could contribute to the behavioral and neural effects that occur with gonadotropin treatment. We cannot be sure whether progesterone plays a similar role because we were unable to detect gonadotropin-induced changes in progesterone levels. However, although it is the case that progesterone is elevated when females exhibit maximal receptivity [Kelley, 1982; Lynch et al., 2005], it has also recently been reported that estrogen administration on its own can evoke phonotaxis responses in female túngara frogs [Chakraborty and Burmeister, 2006]. Consequently, it is possible that both gonadotropin and gonadal hormones influence behavioral and possibly auditory neural responses.

In the present study, gonadotropin-induced modification of activity-dependent gene induction occurs expressly within the LN, the site of gonadal steroid receptor location within the auditory midbrain [Kelley et al., 1975, 1978; Morrell et al., 1975; Kelley, 1980; di Meglio et al., 1987]. Because gonadotropin induces elevated levels of estradiol, it is possible that estradiol in combination with other gonadal hormones mediates this effect. Therefore, it might be that gonadal steroid hormones directly modulate egr-1 expression within the LN. Alternatively, egr-1 expression may be modulated via projections from fore- brain limbic areas, such as the hypothalamus and preoptic area that also concentrate steroid hormones [Endepols and Walkowiak, 1999]. Furthermore, gonadotropins such as HCG can directly alter neural activity within hypothalamic and preoptic neurons by activating $\mathrm{LH}$ receptors, which are present within the hypothalamus of Xenopus laevis [Yang et al., 2007]. If a similar distribution of $\mathrm{LH}$ receptors exists in túngara frogs, then gonadotropin-induced egr-1 expression within the auditory midbrain could result from HCG activation of LH receptors in the hypothalamus that in turn send modulatory projections to the auditory midbrain. Although it is unlikely, gonadotropin might also directly affect neurons in the auditory pathway. Therefore, modification of activity-dependent genes in the midbrain might be due to hormones acting within the auditory midbrain itself or at distant sites that then project to the midbrain. The results presented here cannot distinguish between these possibilities.

Taken together, the results of our studies in female túngara frogs reveal a novel mechanism by which signalers might exploit a receiver's sensory system in a way that increases behavioral responses to their courtship signals. Such a mechanism is useful and possibly essential for coordinating breeding attempts between males and females.

\section{Acknowledgements}

We thank Sabrina Burmeister, Kim Hoke, Mary Ramsey and Ximena Bernal for assistance during the experiments. This work was supported by IBN 0078150 from the National Science Foundation to D.C. Cannatella, M.J. Ryan and W. Wilczynski and NIMH grant RO1 2 MH 057066 to W. Wilczynski. K.S. Lynch was supported by grant T32 MH 18831.

\section{References}

-Allison JD (1992) Acoustic modulation of neural activity in the preoptic area and ventral hypothalamus of the green treefrog (Hyla cinerea). J Comp Physiol A 171:387-395.

- Ball GF, Castelino CB, Maney DL, Appeltants D, Balthazart J (2003) The activation of birdsong by testosterone: Multiple sites of action and the role of ascending catecholamine projections. Ann NY Acad Sci 1007:211-231.

-Bass AH, Zakon HH (2005) Sonic and electric fish: At the crossroads of neuroethology and behavioral neuroendocrinology. Horm Behav 48:360-372.
Burmeister SS, Wilczynski W (2000) Social signals influence hormones independently of calling behavior in the treefrog (Hyla cinerea). Horm Behav 38:201-209.

Burmeister SS, Wilczynski W (2001) Social context influences androgenic effects on calling in the green treefrog (Hyla cinerea). Horm Behav 40:550-558.

-Costagliola S, Urizar E, Mendive F, Vassart G (2005) Specificity and promiscuity of gonadotropin receptors. Reproduction 130: 275-281.
Chakraborty M, Burmeister S (2006) Estradiol induces female receptivity to conspecific calls in the túngara frog. Soc Int Comp Bio Abst 20.7.

Chu J, Wilczynski W (2001) Social influences on androgen levels in the southern leopard frog, Rana sphenocephala. Gen Comp Endocrinol 121:66-73.

Clayton DF (2000) The genomic action potential. Neurobiol Learn Mem 74:185-216.

di Meglio M, Morrell JI, Pfaff DW (1987) Localization of steroid-concentrating cells in the central nervous system of the frog Rana esculenta. Gen Comp Endocrinol 67:149-154. 
-Elkind-Hirsch KE, Stoner WR, Stach BA, Jerger JF (1992) Estrogen influences auditory brainstem responses during the normal menstrual cycle. Hear Res 60:143-148.

-Endepols H, Walkowiak W (1999) Influence of descending forebrain projections on processing of acoustic signals and audiomotor integration in the anuran midbrain. Eur J Morphol 37:182-184.

-Endpols H, Walkowiak W (2001) Integration of ascending and descending inputs in the auditory midbrain of anurans. J Comp Physiol A 186:1119-1133.

-Endepols H, Feng S, Gerhardt HC, Schul J, Walkowiak W (2003) Roles of the auditory midbrain and thalamus in selective phonotaxis in female gray treefrogs (Hyla versicolor). Behav Brain Res 145:63-77.

- Gentner TQ, Hulse SH, Duffy D, Ball GF (2000) Response biases in auditory forebrain regions of female songbirds following exposure to sexually relevant variation in male song. J Neurobiol 46:48-58.

Hinde RA, Steele E (1964) Effect of exogenous hormones on the tactile sensitivity of the canary brood patch. J Endocrinol 30:355-359.

- Hoke KL, Burmeister SS, Fernald RD, Rand AS, Ryan MJ, Wilczynski W (2004) Functional mapping of the auditory midbrain during mate call reception. J Neurosci 24:1126411272.

-Hoke KL, Ryan MJ, Wilczynski W (2005) Social cues shift functional connectivity in the hypothalamus. Proc Nat Acad Sci USA 102: 10712-10717.

-Hoke KL, Ryan MJ, Wilczynski W (2007) Integration of sensory and motor processing underlying social behaviour in túngara frogs. Proc R Soc Lond B 274:641-649.

Kelley DB (1980) Auditory and vocal nuclei in the frog brain concentrate sex hormones. Science 207:553-555.

Kelley DB (1982) Female sex behaviors in the South African clawed frog, Xenopus laevis: Gonadotropin-releasing, gonadotropic and steroid hormones. Horm Behav 16:158-174.

Kelley DB, Lieberburg I, McEwan BS, Pfaff DW (1978) Autoradiographic and biochemical studies of steroid hormone-concentrating cells in the brain of Rana pipiens. Brain Res 140:287-305.

Kelley DB, Morrell JI, Pfaff DW (1975) Autoradiographic localization of hormone concentrating cells in the brain of an amphibian, Xenopus laevis. I. Testosterone. J Comp Neurol 164:47-59.

- Komisaruk BR, Adler NT, Hutchinson J (1972) Genital sensory field: enlargement by estrogen treatment in female rats. Science 178 : 1295-1298.

- Leitner S, Voigt C, Metzdorf R, Catchpole CK (2005) Immediate early gene (ZENK, Arc) expression in the auditory forebrain of female canaries varies in response to male song quality. J Neurobiol 64:275-284.
Lynch KS, Wilczynski W (2005) Gonadal steroids vary with reproductive stage in a tropically breeding female Anuran. Gen Comp Endocrinol 143:51-66.

Lynch KS, Wilczynski W (2006) Social regulation of plasma estradiol concentration in a female anuran. Horm Behav 50:101-106.

Lynch KS, Crews DC, Ryan MJ, Wilczynski W (2006) Hormonal state influences aspects of female mate choice in the túngara frog (Physalaemus pustulosus) Horm Behav 49:450457.

-Maney DL, Cho E, Goode CT (2006) Estrogendependent selectivity of genomic responses to birdsong. Eur J Neurosci 23:1523-1529.

Maney DL, MacDougall-Shackelton EA, MacDougall-Shackelton SA, Ball GF, Hahn TP (2003) Immediate early gene response to hearing song correlates with receptive behavior and depends on dialect in a female songbird. J Comp Physiol A 189:667-674.

- Marler CA, Ryan MJ (1996) Energetic constraints and steroid hormone correlates of male calling behaviour in the túngara frog. J Zool 240:397-409.

Mello CV, Velho TAF, Pinaud R (2004) Song-induced gene expression: A window on song auditory processing and perception. Ann NY Acad Sci 1016:263-281.

Morrell JI, Kelley DB, Pfaff DW (1975) Autoradiographic localization of hormone-concentrating cells in the brain of an amphibian, Xenopus laevis. II. Estradiol. J Comp Neurol 164:63-77.

- Penna M, Capranica RR, Somers J (1992) Hormone-induced vocal behavior and midbrain auditory sensitivity in the green treefrog, Hyla cinerea. J Comp Physiol A 170:73-82.

Potter HD (1965) Mesencephalic auditory regions of the bullfrog. J Neurophysiol 28: 1132-1154.

Rose JD, Moore FL (2002) Behavioral neuroendorinology of vasotocin and vasopressin and the sensorimotor processing hypothesis Front Neuroendocrinol 23:317-341.

Ryan MJ (1980) Female mate choice in a neotropical frog. Science 209:523-525.

Ryan MJ, Rand AS (1998) Evoked vocal response in male túngara frogs: Preexisting biases in male responses? Anim Behav 56:1509-1516.

-Schmidt RS (1984) Mating call phonotaxis in the female American toad: Induction by hormones. Gen Comp Endocrinol 55:150-156.

- Schmidt RS (1985) Prostaglandin-induced mating call phonotaxis in female American toad: facilitation by progesterone and arginine vasotocin. J Comp Physiol A 156:823-829.

Searcy WA (1992) Measuring responses of female birds to male songs. In: Playback Studies of Animal Communication (McGregor PK, ed), pp 175-182. New York: Plenum Press.

- Sisneros JA, Forlano PM, Deitcher DL, Bass AH (2004) Steroid-dependent auditory plasticity leads to adaptive coupling of sender and receiver. Science 305:404-407.
- Sockman KW, Gentner TQ, Ball GF (2002) Recent experience modulates forebrain geneexpression in response to mate-choice cues in European starlings. Proc R Soc Lond B 269:2479-2485.

Thompson RR, Moore FL (2000) Vasotocin stimulates appetitive responses to the visual and phermonal stimuli used by male roughskin newts during courtship. Horm Behav 38:75-85

Thompson RR, Moore FL (2003) The effects of sex steroids and vasotocin on behavioral responses to visual and olfactory sexual stimuli in ovariectomized female roughskin newts. Horm Behav 44:311-318.

-Walpurger V, Pietrowsky R, Kirshbaum C, Wolf O (2004) Effects of menstrual cycle on auditory event-related potential. Horm Behav 46: 600-606.

Wells KD (1977) The social behaviour of anuran amphibians. Anim Behav 25:666-693.

Wilczynski W (1988) Brainstem auditory pathways in anuran amphibians. In: The Evolution of the Amphibian Auditory System (Fritzsch B, Ryan MJ, Wilczynski W, Hetherington TE, Walkowiak W, eds), pp 209231. New York: Wiley.

Wilczynski W, Allison JD (1989) Acoustic modulation of neural activity in the hypothalamus of the leopard frog. Brain Behav Evol 33 : 317-324.

Wilczynski W, Endepols H (2007) Central auditory pathways in anuran amphibians: The anatomical basis of hearing and sound communication. In: Hearing and Sound Communication in Amphibians: Springer Handbook of Auditory Research, vol. 28 (Popper AN, Feng AS, Narins PN, eds). Berlin: Springer-Verlag.

Wilczynski W, Allison JD, Marler CA (1993) Sensory pathways linking social and environmental cues to endocrine control regions of amphibian forebrains. Brain Behav Evol 42:252-264.

-Wilczynski W, Lynch KS, O’Bryant EL (2005) Current research in amphibians: Studies integrating endocrinology, behavior, and neurobiology. Horm Behav 48:440-450.

Wright P, Crow RA (1973) Menstrual cycle: effect on sweetness preferences in women. Horm Behav 4:387-391.

Yang EJ, Nasipak BT, Kelley DB (2007) Direct action of gonadotropin in brain integrates behavioral and reproductive functions. Proc Nat Acad Sci USA 104:2477-2482.

Zakon HH, Smith GT (2002) Weakly electric fish: Behavior, neurobiology and neuroendocrinology. In: Hormones, Brain and Behavior vol. 3 (Pfaff AP, Arnold AM, Etgen SE, Fahrbach RT, Rubin DW, eds), pp 349-375. London: Academic Press, Elsevier Science.

Zar JH (1996) Biostatisical Analysis, 3rd edition. Upper Saddle River, NJ: Prentice Hall. 